МЕТОДИКА ВИКЛАДАННЯ ДИСЦИПЛІНИ «АНГЛІЙСЬКА МОВА ЗА ПРОФЕСІЙНИМ СПРЯМУВАННЯМ (МЕДИЧНА АНГЛІЙСЬКА)» (НА БАЗІ ХУДОЖНІХ ТВОРІВ А. КРІСТІ) ЗА ДОПОМОГОЮ ІНТЕРНЕТ-РЕСУРСУ

\author{
THE TEACHING METHODS OF "ENGLISH LANGUAGE \\ FOR PROFESSIONAL PURPOSE (MEDICAL ENGLISH)" \\ (ON THE BASIS OF A. CHRISTIE'S NOVELS) WITH INTERNET RESOURCE
}

УДК 811.111:61:004.738.5](07.07):

821.111 Твори А. Крісті

DOI https://doi.org/10.32843/2663$6085 / 2020 / 27.33$

\section{Снітовська О.Й.,}

канд. фрілол. наук,

доцент кафедри латинської

та іноземних мов

Львівського національного медичного університету імені Данила Галицького

\section{Царик Г.М.,}

старший виклад кафедри латинської та іноземних мов

Львівського національного медичного університету імені Данила Галицького
Простежено шляхи створення нових комунікативних методик викладання фрахової мови на базі інтернет-ресурсів, соціальної мережі зокрема, з використанням творів зарубіжної літератури, а саме романів А. Крісті з фрармачевтичною медичною лексикою, їх екранізацій. Англійська мова - це сучасна «лінгва фрранка», англійська мова як засіб медичного міжнародного спілкування, така ж, як грецька та латинська в минулому; є важливою передумовою медичної кар'єри, Отже, методики викладання іноземної мови, зокрема у профресійній медичній сререі, на сучасному етапі відповідно до розвитку інформаційного глобального поля повинні розвиватися, оновлюватися, удосконалюватися, адаптуватись до вимог нашого часу для задоволення конкретних академічних і професіійних потреб. Сфера методики викладання англійської мови в медичній ссрері має відповідати інноваційному характеру науки XXI століття. Процес розроблення нових методик, їх обговорення на міжнародних консреренціях та в Україні, подальше впровадження відбувається на сучасному етапі, зокрема українською й англійською мовою. Предметом дослідження $є$ інноваційний метод упровадження професіійної лексики через перегляд автентичних відеосегментів. Питання застосування медичних відеоматеріалів як лексичного аспекту навчання за допомогою повторення висвітлено в чій статті. Під час вибору методів навчання найкращий результат можна отримати в разі поєднання різних методів навчання іноземних мов, адекватних меті та ситуації навчання. Застосування перегляду автентичних медичних відеоматеріалів забезпечує формування всіх компетенцій студента, відповідає принципам особистісно орієнтованого навчання, реалізує потенціал міжпредметних зв'язків. Тому серед малодосліджених і актуальних питань сучасної методології в медичній сфрері $є$ обмін новітнім досвідом вивчення англійської мови в Україні в галузі медицини й охорони здоров'я. Це стосується також студентів вищих медичних навчальних закладів освіти, які в опануванні іноземної мови мають здобути такий рівень комунікативної компетениії, який дозволив би їм користуватися англійською мовою в галузі професійної діяльності.

Ключові слова: комунікативна методика, медична лексика, фрармацевтична термінологія. інтернет-ресурс, аудіо-, відеозасоби.
The article is devoted to the study of the features of the teaching methods of English language for professional purpose (medical English) and foreign literature (on the basis of A. Christie's novels) with Internet resource.

The purposes of the rehearsal way of vocabulary due to videos segments are to develop students general and professionallyoriented communicative language competence in the target language (linguistic, sociolinguistic and pragmatic). This article describes how the lexical approach can be implemented in the classroom, includes detailed discussion of the importance of noticing, the value of repeating texts, and design of lexical exercises, which have a cast bank of lexical chunks and are vital for fluency. The subject of the study is an innovative method of conducting professional vocabulary through the viewing of authentic video segments. The issue of using medical videos as a lexical aspect of repetition learning is covered in this article. When choosing teaching methods, the best result can be obtained by combining different methods of teaching foreign languages, adequate to the purpose and situation of learning. The use of viewing authentic medical videos ensures the formation of all student competencies, meets the principles of personality-oriented learning. The problem of the adequate communication skills in medical professional language is related to the learning of terminological vocabulary, formulas, collocations, etc. The big problem deals with the difficulties in communication of doctors, pharmacists, patients, their relatives, medical students. The problem gets special features where the main goal is the practice in speaking and listening in real English.

The results of the analysis as for the characteristic methods have shown the problems and the ways of their solutions. The absence of practice in speaking and listening of native English may be available in the Internet resources in general, especially in social net.

The article contains examples of medical vocabulary, pharmaceutical terminology, dialogues of doctors, pharmacists and patients in fiction, in A. Christie's novels and their filming. The texts and the movies have the functions of learning. The productive resource of communication is the Facebook group and the page of a teacher for his students.

Key words: communicative method, medical vocabulary, pharmaceutical terminology, Internet resource, audio and video means.
Постановка проблеми в загальному вигляді. Актуальність дослідження зумовлюється комплексом екстра- й інтралінгвальних чинників у соціолінгвістичному аспекті загалом і в галузі медицини зокрема; потребою мовознавства в розробленні та впровадженні інтерактивних методів загалом; роз- ширенням міжнародних зв'язків України 3 іншими країнами на науковому рівні, суспільною потребою у кваліфрікованих спеціалістах у медичній сорері, що володіють англійською мовою; не лише необхідністю спілкування фрахівців у сфері охорони здоров'я, але для комунікації професіоналів та непрофесіоналів. 
За Загальноєвропейськими рекомендаціями, студенти вищих немовних закладів освіти повинні опанувати загальновживану та професійно орієнтовану іноземну мову [4, с. 134]. Читання оригінальної медичної літератури розглядається як основне джерело отримання новітньої інфрормації спеціального характеру, проте студенти швидко засвоюють термінологію, орієнтуються в науковій літературі, водночас їм не вистачає навичок безпосереднього спілкування з учасниками процесу лікування -лікарями, медперсоналом, студентами-медиками, пацієнтами та їхніми родичами. Наявні недоліки мовної підготовки студентів медичних вишів (дефіцит часу, вивчення тільки на 1-2-му курсах, коли ще не сфрормовані знання медицини рідною мовою, недостатній рівень компетенції вступників, брак методичного ефективного курсу) також зумовлюють вибір теми.

На сучасному етапі постійне збільшення можливостей застосування нових методик та вдосконалення вже наявних, необхідність їхньої ефективності зумовлюють актуальність вибраної теми дослідження.

Основними недоліками організації мовної підготовки студентів у медичному виші є дефіцит часу, відведеного на іноземну мову; низький рівень мовної компетенції абітурієнтів; відсутність методики навчання іноземної мови, що враховує специфріку міждисциплінарної підготовки студентів-медиків.

Нині все більше уваги приділяється питанням навчання іноземної мови як мови професійної взаємодії, коли читання оригінальної медичної літератури розглядається як основне джерело отримання новітньої інорормації спеціального характеру, що сприяє підвищенню рівня профресійної компетентності випускників немовних вишів.

Проте студенти досить швидко опановують саме термінологію, зокрема англійською мовою, проте комунікативні навички залишаються нерозвиненими. Студент може орієнтуватися в науковій медичній літературі, стежити за англомовними науковими медичними джерелами, проте не може спілкуватися 3 колегами під час конференцій, міжнародних проєктів, під час звичайної телефонної розмови 3 родичами пацієнта-іноземця (навіть якщо він не англієць, а громадянин будь-якої країни, спілкування потребує знання англійської). У вишах застосовують таку методику навчання іноземної мови для студентів немовних спеціальностей, яка базується на перекладі навчальних спеціалізованих текстів, засвоєнні термінології та вивчені граматики. Така методика допомагає розвивати навички читання, інтерпретації текстів, опанування фрахової термінології [3].

Дана стаття присвячена саме комунікативному аспекту у вивченні англійської студентами-медиками за допомогою сучасних інтернет-ресурсів як в аудиторії, так і дистанційно та позакласно.
Мета статті - дослідити особливості новітнього підходу до вивчення англійської мови студентами-медиками. Поставлена мета передбачає розв'язання таких конкретних завдань:

- систематизувати матеріал щодо вже відомих та оновлених сучасних методів навчання англійської студентів-медиків;

- проаналізувати ресурси для фрормування комунікативних навичок студентів-медиків;

- визначити продуктивні способи застосування викладачами нових методів навчання англійської студентів-медиків.

Об'єктом нашого дослідження $€$ новітні методи вирішення проблеми вивчення англійської мови студентами-медиками.

Предметом - особливості комунікативних методик, пропонованих на основі сучасних ресурсів.

Матеріалом для дослідження були тексти англомовної літератури з фармацевтичною лексикою та діалогами «пацієнт - фахівець - нефахівець», їх переклади українською мовою, а також фррагменти цих же екранізованих текстів, а саме: твори Агати Крісті "Death in the clouds" («Смерть за хмарами»), "The Pale Horse" («Блідий кінь»), "The Mysterious Affair at Styles" («Tаємничий випадок у Cтайлзі»), "Dumb witness” («Німий свідок»), "The blue geranium" («Синя квітка герані»), "Five little pigs" («П'ять поросят»), “The yellow iris" («Жовті іриси»), "Pockets full of rye" («Кишені, повні жита»), “Aspennest” («Осине гніздо»), "An Autobiography" («Автобіографрія»), відповідні епізоди англомовного серіалу "Agatha Christie: Poirot” («Пуаро Azати Kpicmi») (1989-2013 рр.) 3 англійськими субтитрами та українською (за необхідності) версією серіалу [41; 42].

Виклад основного матеріалу. Вивчати англійську мову для медиків краще за сценаріями спілкування між лікарем і пацієнтом, відпрацюванням діалогів на практиці. Курс англійської повинен базуватися на закріпленні лексичного і граматичного матеріалу в рамках програми навчання, яка імітує реальні життєві ситуації. Медичним працівникам, які вивчають англійську мову, необхідно практикувати мовні навички, від складання історії хвороби, огляду пацієнта до спілкуванням 3 пацієнтом, призначення й опису курсу лікування, повідомлення пацієнту поганих або добрих новин 3 урахуванням менталітету і способу мислення англомовних громадян закордонних держав.

Зазвичай для навчання або роботи в англомовних країнах із мовних іспитів досить скласти IELTS чи TOEFL, далі постане необхідність складати кваліфрікаційний United States Medical Licensing Examination (USMLE) у двох розділах: Basic Science та Clinical Science [15]. Clinical Skills Assessment (іспит у ситуації з реальним хворими) вимагає впевненості у професійних компетенція та володінні англійською на високому рівні. 
Варто взяти до уваги, що тести жодних додаткових знань не дають, це лише перевірка й атестація вже наявного «багажу». Тому тестові методики не служать для вивчення мови. Для медиків «чарівної пігулки» (як каламбур) немає - миттєво без труднощів освоїти мову нереально, це праця, зусилля, час. Тому нові методики і викладачі, що їх створюють, допомагають студентам, спрямовують їх до успішного опанування мови [16].

Проте не варто скасовувати традиційні методики, що можуть становити фундамент методик.

Один із найсерйозніших методів вивчення іноземної мови - лінгвосоціокультурний, що передбачає апеляцію до такого компонента, як соціальне й культурне середовище.

Комунікативний підхід, як випливає 3 його назви, спрямований на практику спілкування. Комунікативна методика спрямована саме на можливість спілкування. Із 4-х навиків, на яких базується мовний тренінг (читання, письмо, говоріння та сприйняття мови на слух), підвищена увага приділяється саме двом останнім.

Оксорордський і кембриджський підходи до мови об'єднує те, що в основу роботи більшості курсів покладена комунікативна методика, інтегрована $з$ деякими традиційними елементами викладання. Вона передбачає максимальне занурення студента в мовний процес.

Отже, викладачі англійської мови для спеціальних цілей (студентам-медикам) опиняються в ситуації, коли вони повинні скласти курс, який точно відповідає потребам групи студентів, але в умовах обмеженого часу підготовки. Найпростіше рішення, на наш погляд, - знайти метод доступний на ринку, заснований на використанні мультимедійних ресурсів. Наявність на ринку методів навчання, як-от командна робота, доступ до справжніх документів (брошури для пацієнтів, медичні анкети, записи та довідкові матеріали, що використовуються в англомовних лікарнях), вебсайти, телевізійні шоу або фільми для медичних цілей - це ефективні ресурси для розроблення курсу $[17 ; 18 ; 19]$.

Один із нових методів для викладача - спілкування зі студентами, розміщення для них матеріалів, перевірка засвоєння на власній, спеціально створеній сторінці соціальної мережі «Фейсбук» [14].

Деякі виші 2017-2018 навчального року переходили тимчасово на дистанційне навчання, отже, така методика стає не єдиною, проте необхідною.

За цим методом необхідно викладачеві створити групу у Facebook (приватні / запрошувати лише) і використовувати стіну як дошку для обговорення. Студенти отримують сповіщення на домашній сторінці. Сповіщати студентів необхідно терміново - публікація на Facebook приверне увагу студентів набагато швидше, ніж електронна пошта, тому що більшість із них регулярно перевіряють Facebook. Альтернативою групі $€$ сторінка франів, яка має перевагу в тому, що оновлення статусу викладачем відображатимуться для студентів. Недоліком можна вважати те, що деякі студенти вимикають живий ефрір і бачать лише статуси своїх друзів. Якщо дозволити своїм студентам дружити, їм надається необмежений доступ, але, що важливіше, оновлення статусу викладачем будуть видні їм вдома (якщо вони не заблокують вас уручну). Недоліком також можна вважати те, що занадто багато інформації буде виявлено 3 обох сторін, якщо тільки викладач та студенти не встановлюють списки з обмеженим доступом [20].

Виклик для педагога полягає у виборі, послідовності та виконанні завдань таким чином, щоб об'єднати фрокус та сенс, зосередившись на формі. Викладач англійської мови може відчувати себе незручно через відсутність навичок у медицині, проте повинен бути фрахівцем у медичній англійській мові, може визнати незнання спеціальної дисципліни, але ніколи не повинен створювати враження, що сам предмет є нецікавим або неважливим. Саме викладач $є$ організатором групової взаємодії (ідеальним колективом для вивчення іноземної мови натепер уважається група 3 10-15 осіб, студентів групи (можна поділити на 2), оскільки саме така кількість людей може спілкуватися один з одним і максимальним ефектом, інтересом і користю, зокрема на «Фейсбуці»).

Викладач теж не обмежений у виборі методів і прийомів навчання: від ігор і тренінгів до синхронного перекладу; в організації занять; у виборі підручників і навчальних посібників: від вітчизняних видань до продукції Оксорорду, Кембриджу, Лондона, Нью-Йорка і Сіднея. Учитель тепер може підбирати, творити, комбінувати, видозмінювати.

Як матеріал для занять можна використовувати ресурси з інтернету. Наприклад, платформа medtube.net містить різноманітні медичні ролики на більш складні і серйозні тематики. На платфрормі futurelearn.com представлені курси медичної тематики англійською мовою. Також можна використовувати спеціальні платорорми, де спілкуються лікарі-колеги, як-от forums.studentdoctor або sermo. На цих фрорумах студенти-медики зможуть збагатитися досвідом медиків-практиків, отримати поради, поспілкуватися на цікаві теми (англійською) $[21 ; 22 ; 23]$.

3 огляду на те, що сприйняття на слух іноземної мови відбувається непросто, особливо на початковому етапі (англійська викладається на 1-2 курсах), варто першими включити в навчання невеликі за тривалістю аудіо- і відеоматеріали. Добре розуміння потребує навику, а на такого типу матеріалах натренувати найлегше. Продуктивність підвищується, якщо повторювати вголос фррази 3 аудіо або відео за носієм мови, намагатися зрозу- 
міти їхній зміст із контексту. Безумовно, якщо просто слухати англійську мову щодня без додаткового опрацювання тексту, це теж дасть ефект. Але ще більші результати у розвитку мовних навичок дає виконання додаткових завдань. Наприклад, розмовна мова чудово тренується через переказ і обговорення почутого з іноземним співрозмовником, а читання і словниковий запас - через роботу з текстом аудіо або відео.

Що стосується фрільмів, серіалів та інших відеоматеріалів, то незаперечний плюс роботи з ними полягає в тому, що те, що відбувається на екрані, уже є підказкою до сюжету. Розуміння йде через інтонації, жестикуляцію, інші дії героїв на екрані. До того ж довге за тривалістю відео завжди можна розділити на частини, працювати з кожною окремо.

У мовленні є чотири основні навички: 1) розуміння на слух (усне мовлення, ідіоми, реалії культури); 2) усне мовлення (швидкість, грамотність, вимова, етикет); 3) читання (вимова, розуміння змісту); 4) письмо (правопис, побудова фррази, культурні норми). Важливі всі навички, але здебільшого людей навчають граматики, набору слів, а потім людина не розуміє, що їй говорять, не може правильно відповісти, поводиться неадекватно.

Ми вибрали декілька творів А. Крісті, а також екранізації за ними. Отже, відразу освоюються і мова, і етикет спілкування, і реалії англомовного середовища [32-40].

Для максимальних результатів студенти слухають і повторюють уголос матеріали записаного викладачем зі сторінки «Фейсбуку» уроку в будьяку вільну хвилину: у дорозі, спортзалі, на прогулянці (проте студенти-медики з гуртожитку дещо обмежені вдома). Навіть п'ять хвилин під час перерви мають значення, заняття самостійно за браком часу можуть бути нетривалими, але систематичними, кожного дня, навіть кілька разів на день. Відомі випадки, коли студент завантажує відео собі на смартфон, і, якщо не можна користувалися звуком, може звіряти картинку із субтитрами під час навіть не дуже тривалої поїздки (якщо дозволяють умови у громадському транспорті).

Студентам разом із матеріалами надаються рекомендації: 1. Повторіть за кожним героєм епізоду (англомовний актор) - у ту секунду, коли він робить паузу. 2. Вимовте фрразу перед оповідачем і повторіть після оповідача ((якщо в епізодах $€$ авторський текст). У сценках здебільшого це діалоги), виберіть собі роль (наприклад, Еркюль Пуаро або його друг Гастінгс). 3. Запишіть фрази за діючими особами, повторюйте водночас їх уголос поки пишете. 4. Запишіть ваші відповіді. 5. Запишіть себе на диктофрон, прослухайте себе, аналіз дасть ефективний результат - ви почуєте помилки вимови, інтонації, у граматиці.

Викладач вибирає короткі фррагменти літературних творів (ті, що стосуються фраху), про- понує різноманітні комунікаційні / письмові завдання. Наприклад, після прочитання роману (або фррагментів) А. Крісті “The Mysterious Affair at Styles" («Таємничий випадок у Стайлз») [32] студентам було запропоновано вільно обговорити процес отруєння отрутою (poison), описати його 3 різних поглядів. Студенти також були зацікавлені в дискусіях із різних аспектів медичної практики й етики. Цікавим є той фракт, що інший роман А. Крісті, “The Pale Horse” («Блідий кінь»), урятував принаймні два життя після того, як читачі визнали симптоми отруєння талієм 3 опису у книзі. У 1975 р. А. Крісті отримала листа з Латинської Америки, від жінки, яку врятували від повільного отруєння її чоловіком, а в 1977 р. медсестра, яка читала «Блідого коня», визначила, що дитина під її опікою страждала від отруєння талієм. У 1971 р. завдяки цій книзі був схоплений серійний убивця Грем Фредерік Янг, який отруїв кілька людей, трьох смертельно. Лікар зі Скотланд-Ярду читав “The Pale Horse" і підтвердив, що було фрактично отруєнням талієм [35].

Щоб пояснити причини вибору творів для вивчення англійської медичної мови, зокрема творів А. Крісті, наведемо фракти. Сорок один твір (61\%) письменниці містить детективну історію, пов'язану з отрутою. «Королева детективу» спиралася на власний реальний фармацевтичний досвід під час Першої та Другої світових війн. Під час Першої світової А. Крісті пішла волонтером у шпиталь Торки, свого рідного міста. У своїй "An Autobiography" («Автобіографія») А. Крісті згадує, що під час її роботи в амбулаторії вона вперше задумала скласти детективну історію [40]. У багатьох іiї книгах сам процес отруєння стає сюжетним пунктом. На початку письменницької кар'єри А. Крісті такі речовини, як миш'як та стрихнін, усе ще перебували в медичному застосуванні. Передозування призначених препаратів, а також використання хибних або підроблених рецептів є загальними рисами вигаданих отруйників А. Крісті, багато 3 яких працюють у медицині. 3 токсичним ефектом білого фросфрору пов'язаний сюжет “Dumb witness” («Німого свідка») (ним виявися песик отруєної господині) [36]. У момент смерті в дами 3 рота виходить зелений дим (результат реакції білого фосорору з повітрям). Реакція лакмусового папірця використана в “The blue geranium" («Синя квітка герані»), коли змінився колір квітів на шпалерах [33]. Кураре, з яким колись ознайомив її колега, А. Крісті використала майже п'ятдесят років потому у «Блідому коні» [40]. Помилкою було б уважати А. Крісті «старомодною аптекаркою», що зналася тільки на «викопних» ліках-отрутах. Під час Другої світової вона знов працювала волонтером-провізором у Шпиталі Університет- 
ського коледжу в Лондоні та стежила за досягненнями у фрармацевтиці [40].

У результаті роботи помічником провізора у шпиталі та через рішення писати роман з'явилося видання "The Mysterious Affair at Styles" («Taємничий випадок у Стайлз»). У 1921 р. в The Pharmaceutical Journal 3'явився огляд книги, де було зазначено: «Цей роман має рідкісну заслугу того, що він правильно написаний». Письменниця зібрала певну медичну бібліотеку, окрасою якої була книга "Martindale's Extra Pharmacopoeia". Протягом усього свого письменницького життя А. Крісті вивчала сприймання отрути та ліків [40].

Отже, як зазначалося раніше, детективний роман англійської письменниці А. Крісті "Тhе Mysterious Affair at Styles" (за браком часу 3 іншими, не менш цікавими 3 погляду фрармацевтики, ознайомлення відбувається оррагментарно) було обрано для обговорення зі студентами-медиками як метод поєднання основних чотирьох навичок мовлення. На сторінці «Фейсбуку» надається посилання на письменницький текст, а також на епізод серіалу. Якщо часу замало, викладач вказує конкретні сторінки, де вжита фрарм-лексика. Перегляд фрільму «оживлює» авторський текст «культурним» компонентом - пейзажі Англії, стиль життя, одяг, транспорт, звичаї та традиції постають у рухомій формі, стають асоціативними позначками. Жести, міміка, інші невербальні засоби теж сприяють засвоєнню лексики, інтонації. До речі, англійською мовою (ані в перекладах, ані в субтитрах не відображено) у героя наявний іноземний акцент, що ілюструє деякі помилки, яких можуть уникнути студенти.

Зауважимо, у текстах наявні майже всі граматичні аспекти, трапляються практично всі часові форми, пряма мова, уживання артиклів тощо, наприклад: had been invalided (Past Perfect tense, Passive Voice); has been poisoned (Present Perfect tense, Passive Voice); was lying (Past Continuous); the symptoms (означений артикль); on toxicology (з токсикології, використання прийменників); it isn't strychnine, is it? (різновид питального речення); my mother's death (присвійний відмінок); There was no strychnine present (надалі потребує лексичної трансформації антонімічний переклад); if Mr. Inglethorp knew that his wife would be poisoned last night (умовне речення); Lawrence's intelligence («хибні» друзі перекладача: розумові здібності Лоуренса, а не інтелігентність Лоуренса); Liq. Strychnine Hydro-clor. (скорочення), що відповідає рівню підготовки студентів 1-2 курсів, i, якщо студент має вищий рівень, слугуватиме повторенням або закріпленням знань.

Викладач дає завдання виписати або записати на носії озвучення, з подальшим обгово- ренням на фрорумі. Викладач свідомо пропонує користуватися тільки англомовними субтитрами, уникати користування наявними перекладами українською відомих українських перекладачів (В. Хижняка, В. Шовкуна й інших). У даному разі нас цікавили не засоби відтворення тексту профресійними перекладачами. Тому переклад у прикладах нижче досить загальний, такий, що можуть запропонувати самі студенти для розуміння контексту.

Отже, у романі-детективі виявлено достатню кількість фрраз, частину яких ми наводимо, із фармацевтичною або іншою медичною лексикою (виділено жирним курсивом) [32]:

- I had been invalided home from the Front (зміст: поранений (капітан Гастінгс) був відправлений додому із фрронту (Першої світової);

- Lawrence, He had qualified as a doctor but early relinquished the profession of medicine (зміст: один із героїв був доктором, проте залишив медичну профресію);

- Mrs. Inglethorp was lying on the bed, her whole form agitated by violent convulsions (зміст: вона лежала на ліжку в конвульсіях);

- The violence of Mrs. Inglethorp's attack seemed to be passing (зміст: напад, здавалося, відступав);

- A fresh access of pain seized the unfortunate old lady (зміст: новий напад болю охопив стару леді);

- The doctor reached the bed, and seizing her arms worked them energetically, applying what I knew to be artificial respiration (зміст: доктор енергійно працював їі руками, що, я знав, було итучним диханням);

- They were quite tetanic in character (зміст: за характером дуже схожі на правець);

- I believe she has been poisoned! (змісm: Вважаю, ï отруїли!);

- That neither Dr. Wilkinsn or myself could give a death certificate under the circumstances (змісm: ані доктор Вілкінс, ані я не можемо надати свідоцтво про смерть у зв'язку з обставинами),

- Well, strychnine is a fairly rapid poison (зміст: стрихнін - дуже швидкодіюча отрута);

- Its effects would be felt very soon, probably in about an hour. Yet, in Mrs. In glethorp's case, the symptoms do not manifest themselves until five o'clock the next morning: nine hours! But a heavy meal, taken at about the same time as the poison, might retard its effects, But, according to you, she ate very little for supper, and yet the symptoms do not develop until early the next morning! (зміст: ефрект міг би почуватися досить скоро, може, за годину. Проте в цьому випадку симптоми не виявили себе до п'ятої наступного ранку: дев'ять годин! Але важка їжа водночас з отрутою відклала ефект, але 
вона мало їла за вечерею, і все ж симптоми не розвинулися);

- Great authority on toxicology, I believe (зміст: великий авторитет у токсикології, уважаю);

- Can you tell me what they were? Sulphonal? Veronal? No, they were bromide powders (3місm: Сульфонал? Веронал? Ні, порошки броміду);

- It is Mr. Mace, from the chemist's shop (зміст: це містер Мейс, з аптеки);

- They do say he lowered his voice cautiously it's poison? (зміст: чи правда, ї отруїли?);

- In a few brief words, he summed up the result of the post-mortem (зміст: він підсумував резульmamu розтину);

- She was at that moment in a typical tetanic convulsion (зміст: у неї були типові конвульсії правця);

- It can be detected in a solution of 1 in 70000 (зміст: він може бути визначений у пропорції 1 до 70 000);

- It still seems to meth at my mother's death might be accounted for by natural means (зміст: мені досі здається, що смерть матері із природних причин);

- Strychnine is, in a certain sense, accumulative poison (зміст: стрихнін, у деякому сенсі, кумулятивна, накопичувальна отрута);

- There would have to be a long period of chronic symptoms (зміст: мусив би бути довгий період для хронічних симптомів);

- That Mrs. In glethorp may have inadvertently taken an overdose? Three, or even four doses, would not have resulted in death (зміст: чи могла б вона передозувати? Три, навіть чотири дози не привели б до смерті);

- Poiro directed the car to the Analytical Chemist [14] (зміст: Пуаро спрямував авто до лабораторії Аналітична Хімія);

- I'll admit that it wasn't he who bought strychnine at the chemist's shop (зміст: припускаю, це не він купив стрихнін в аптеці);

- That is a rsenic - not strychnine (зміст: миш'як - не стрихнін);

- He never went near the poison cupboard the day we were there! (зміст: він не ходив повз шафоки з отрутою);

- a tiny bottle in the top poison cupboard of the dispensary in the Red Cross Hospital at Tad minster (зміст: малесенька пляшечка у шафиі з отрутою у провізорській у Шпиталі Червоного Xpecma);

- only occasionally for pills (зміст: тільки іноді для пігулок);

- Liq. Strychnine Hydro-clor. that is used in most medicines (зміст: рідкий стрихніну гідрохлорид використовується в більшості ліків);

- The phial was that already recognized by the chemist's assistant, a tiny bottle of blue glass, containing a few grains of a white crystalline powder, and labelled: Strychnine Hydrochloride. POISON (зміст: сосуд було впізнано помічником аптекаря, маленька пляшечка з декількома гранулами білого кристалічного порошку, з етикеткою «Стрихніну гідрохлорид. Отрута»);

- A narcotic taken with strychnine will delay the action of the poison for some hours (зміст: наркотик разом зі стрихніном відкладає дію отрути на кілька годин);

- Her medicine! (зміст: їі ліки!);

- I will read you an extract from a book on dispensing which I found in the Dispensary of the Red Cross Hospital at Tadminster. The following prescription has become famous in text books: Strychninae Sulph <...> gr. I Potass Bromide $<\ldots>$ 3vi Aqua ad $<\ldots>3 v i i i$ Fiat Mixstura. This solution deposits in a few hours the greater part of the strychnine salt as an insoluble bromide in transparent crystal (зміст: нерозчинний бромід у прозорих кристалах)

За підрахунками, найчастіше вживані слова 3 медичної лексики poison (ompyma) - 18 разів, strychnine (стрихнін) - 22 рази, що водночас $€$ фармацевтичними термінами; слова, що позначають форму препаратів: Liq., powders, pills (рідкий, порошок, пігулки), назви англомовної документації з медицини та юридичної тематики: post-mortem (розтин), a death certificate (свідоцтво про смерть); назви медичних установ у Великій Британії: the dispensary (провізорська), Red Cross Hospital (Шпиталь Червоного Xpecma), Analytical Chemist (назва установи хімічного аналізу), chemist's shop (аптека); назви захворювань: tetanic (правець) тощо. Отже, художній твір насичений спеціальною лексикою медичного спрямування. Частотність повторювання в тексті сприяє засвоюванню.

Водночас (після або перед читанням тексту роману) рекомендовано переглянути екранізацію. Напружені сухі діалоги з роману "Mysterious Affair at Styles" («Таємничий випадок у Стайлз») [32] відтворюються на екрані за допомогою тембру голосу, інтонації носія мови, невербальними засобами, а саме виразом обличчя, жестами, на відповідному тлі, що сприяє засвоєнню. Також екранізація «розведена» розмовними зворотами, додаванням зрозумілих реплік, як-от на перших хвилинах фрільму невеличкий діалог у рецепції шпиталю дозволяє почути оригінальну англійську мову у відтворенні непрямої мови у пряму (у тексті слова автора капітана Гастінгса, від його особи відбувається розповідь, на екрані - живий діалог); також, зважаючи на те, що фрільм був знятий у 1990 р., трохи застарілі вирази з тексту 20-х рр. були оновлені відповідно до вимог часу та вимог телевізійного продукту. Якщо сприймання на слух або субтитри виклика- 
ють труднощі, варто звернутися до повного тексту сценарію (script) [39].

Студенти можуть вибрати роль одного із трьох лікарів (син померлої, особистий доктор, місцевий муніципальний лікар), описати коротко історію з їхнього погляду, або інших учасників, за допомогою медичної лексики, фрармацевтичної термінології, або висловити власну думку майбутнього медика. Обговорення можуть починатися в аудиторії та продовжуватися на фрорумі, на сторінці «Фейсбуку» викладача, який може контролювати й оцінити таким чином засвоєння матеріалу.

Висновки. У процесі відпрацювання запропонованої методики поєднання художніх текстів з елементами медичної тематики 3 їх екранізаціями рекомендується співпрацювати з фахівцями в галузі охорони здоров'я та зі студентами з метою вибору вмісту, орієнтованого на навчальні матеріали, підбору відповідних заходів у класі та на сторінці «Фейсбуку». Це тривалий і постійний процес, що відповідає розвитку новітніх технологій із фаху медицини й інформації, він не завершений, i, на нашу думку, має перспективи розвитку. Сучасний аспект у методиці викладання англійської мови студентам-медикам, запропонований у даній статті, може бути використаний як складова частина в нових методиках викладання англійської мови для спеціальних цілей.

Перспективу подальшого дослідження бачимо в розширенні й оновлені матеріально-технічної бази для використання нових технологій, збільшення списку творів і екранізацій із медичною тематикою, упровадження фракультативів та спецкурсів для студентів старших курсів, в обміні досвідом викладачів із новітніх технологій та методики вивчення англійської мови студентамимедиками.

\section{БІБЛІОГРАФІЧНИЙ СПИСОК:}

1. Англійська мова за професійним спрямуванням: Стоматологія - English for Professional Use: Dentistry : підручник / І. Романко та ін. Київ : ВСВ «Медицина», 2015. 224 c.

2. Голод Р. Англійська мова для студентів-медиків : підручник для студентів-медиків вищих медичних навчальних закладів IV рівня акредитації.

3. Демянчук О. Вибір есрективних методів навчання іноземної мови студентами непрофрільних спеціальностей за визначеними критеріями. URL: www.erjournal.ru/journals_n/1358977530.pdf.

4. Загальноєвропейські рекомендації 3 мовної освіти: вивчення, викладання, оцінювання / наук. ред. укр. вид. С. Ніколаєва. Київ : Ленвіт, 2003.

5. Юкало В. Мовні стереотипи в комунікаціях лікаря : авторефр. дис. ... канд. фрілол. наук. Київ, 2003. 24 c.

6. Англо-український ілюстрований медичний словник Дорланда : у 2-х т. Львів : Наутілус, 2002. 2688 c.
7. Вакулик І. Латинсько-український та українськолатинський словник ветеринарно-медичних термінів. Київ, 2010. 248 с.

8. URL: http://www.imdb.com/list/ls009077670/.

9. URL: https://www.google.com.ua/search?biw=1318 \&bih=527\&ei=xhWsWrz6IMnLwQKcuJrIAQ\&q=side+effe cts+\%D1\%81\%D0\%BC\%D0\%BE\%D1\%82\%D1\%80\%D 0\%B5\%D1\%82\%D1\%8C+\%D0\%BE\%D0\%BD\%D0\%BB \%D0\%B0\%D0\%B9\%D0\%BD\&oq=side+effect\&gs_l=psyab.1.8.0l10.2583.21556.0.32301.13.13.0.0.0.0.177.1615 .0j12.13.0...0...1.1.64.psy-ab.0.13.1781.6.0i20i263k1j35i 39k1j0i67k1j0i131k1.209.V53Mt1xwREY.

10. URL: https://www.oxfordlearnersdictionaries. com/definition/english/hercule-poirot.

11. Medical Writing in Early Modern English. URL: www.cambidge.org books.google.ru/books?isbn= 1139493833.

12. English for medical Purposes. URL: http://www. oed.hertford.ox.ac.uk/main/content/view/.../169.

13. Tim Albert. The a-zof medical writing. BMJ Books 2000. Tim Albert Training, Surrey, UK.

14. URL: https://www.google.com.ua/search? ei=T9q7WqivH8fdwQL1qpXYDw\&q=Analytical+C hemist+-+\&oq=Analytical+Chemist+-+\&gs_l=psyab.12.0i22i30k1l10.6107.10922.0.13512.5.5.0.0.

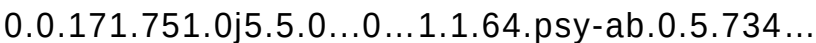
0j0i67k1.0.byl5H3cpQE4.

15. URL: www.usmle.org/.

16. URL: https://enguide.ua/magazine/angliyskiydlya-rabotnikov-mediciny-leksika-grammatika-sovetypo-izucheniyu.

17. URL: https://www.filmpro.ru/series/selections/ 58658-.

18. URL: https://www.vokrug.tv/listing/filmy_pro/ filmy_pro_vrachei/.

19. URL: afisha.bigmir.net/movie/articles/215627-10luchshih-medicinskih-serialov.

20. URL: http://www.fctl.ucf.edu/TeachingAnd LearningResources/CourseDesign/Assessment/ content/101_Tips.pd.

21. URL: https://www.futurelearn.com/courses/ categories/health-and-psychology-courses.

22. URL: https://forums.studentdoctor.net/forums/ pharmacy.122/.

23. URL: https://www-forums.studentdoctor.net/.

24. URL: https://www.theguardian.com/books/2015/ sep/05/agatha-christies-poisons-crime-fiction.

25. URL: https://daily.jstor.org/agatha-christiepharmacist/.

26. URL: https://www.chemistryworld.com/feature/ agatha-christie-the-queen-of-crime-chemistry/8911. article.

27. URL: https://www.amnh.org/explore/news-blogs/ on-exhibit-posts/poison-in-literature-agatha-christie/.

28. URL: https://www.teatime-mag.com/magazines/ 186-de/.

29. URL: https://www.thedailybeast.com/agathachristie-was-actually-a-poison-master.

30. URL: https://uk.wikipedia.org/wiki/\%D0\%97\%D 0\%B0\%D0\%B3\%D0\%B0\%D0\%B4\%D0\%BA\%D0\%B E\%D0\%B2\%D0\%B0 \%D0\%BF\%D1\%80\%D0\%B8\% D0\%B3\%D0\%BE\%D0\%B4\%D0\%B0_\%D0\%B2_\%D 
0\%A1\%D1\%82\%D0\%B0\%D0\%B9\%D0\%BB\%D0\%B7\%D1\%96.

31. URL: https://uk.wikipedia.org/wiki/\%D0\%91\%D0 \%BB\%D0\%B8\%D1\%81\%D0\%BA\%D1\%83\%D1\%87\% D0\%B8\%D0\%B9_\%D1\%86\%D1\%96\%D0\%B0\%D0\%B D\%D1\%96\%D0\%B4.

32. URL: https://uk.wikipedia.org/wiki/\%D0\%9A\%D 0\%B8\%D1\%88\%D0\%B5\%D0\%BD\%D1\%8F,_\%D0\%B F\%D0\%BE\%D0\%B2\%D0\%BD\%D0\%B0_\%D0\%B6\%D 0\%B8\%D1\%82\%D0\%B0.

33. Christie A. The Mysterious Affair at Styles. URL: http://baloo.co/episode/the-mysterious-affairat-styles-0100216 ; URL: http://engshop.ru/TheMysterious-Affair-a-Styles-skachat/ ; URL: http:// loveread.ec/read_book.php?id=2642\&p=23.

34. Christie A. The blue geranium. URL: https:// javalibre.com.ua/java-book/book/Trinadcyat_ zagadkovih_vipadkiv_Agata_Kristi.

35. Christie A. Death in the clouds. URL: engshop. ru/Agatha_Christie_Deathin_the_Clouds_id157/ www.imdb.com/title/tt0094525/.
36. Christie A. The Pale Horse. URL: http://www. agathachristie.com/stories/the-pale-horse www.imdb. com/title/tt0094525/.

37. Christie A. Dumb witness. URL: http://engshop.ru/ Dumb-Witness-skachat/ www.imdb.com/title/tt0094525/.

38. Christie A. Five little pigs. URL: http://engshop. ru/Five-Little-Pigs-skachat/ tt0094525/.

39. Christie A. Pockets full of rye. URL: http:// engshop.ru/A-Pocket-Full-of-Rye-skachat/www.imdb. com/title/tt0094525/.

40. Christie A. Script of subtitles. URL: http://DJJ. HOME.SAPO.PT/.

41. Christie A. An Autobiography. URL: https://www. goodreads.com/book/.../16301.An_Autobiograp; URL: https://www.opensubtitles.org/.../sublanguageid.../ idmovie-9.

42. URL: http://moviestape.net/katalog_serialiv/ detektyvy/7143-puaro-agati-krst.html.

43. URL: https://www.youtube.com/watch?v= 1CZA9ZMG4VE. 